\title{
Öğretmenlerin Psikolojik Dayanıklılık ile Tükenmişlik Düzeyleri Arasındaki İlişki ${ }^{1}$
}

\author{
DOI: 10.26466/opus.937692
}

\author{
* \\ Durmus Bozkurt ${ }^{*}$ A. Faruk Levent** \\ * Öğretmen, MEB, İstanbul/Türkiye \\ E-Posta: yudubo@gmail.com \\ ORCID: $\quad \underline{0000-0001-9955-5687}$ \\ ** Doç. Dr., Marmara Üniversitesi, Atatürk Eğitim Fakültesi, İstanbul/Türkiye \\ E-Posta: $\quad \underline{\text { faruk.levent@marmara.edu.tr }} \quad$ ORCID: $\underline{\text { 0000-0003-3429-6666 }}$
}

\section{Öz}

Bu araştırmanın amacı, öğretmenlerin psikolojik dayanıklılığı ile tükenmişlik düzeyleri arasındaki ilişkinin incelenmesidir. Bilimsel olarak nicel araştırma yöntemlerinden ilişkisel tarama modelinin kullanıldığı bu araştırmanın örneklem grubu, 2019-2020 eğitim-öğretim yılında İstanbul ili Bağcllar ilçesindeki resmî ilkokul, ortaokul ve liselerde görev yapan toplam 4523 öğretmen arasından seçkisiz basit tesadüfi örnekleme yöntemiyle belirlenen 354 öğretmenden oluşmaktadır. Veri toplama aracı olarak öğretmenlerin demografik verilerine ilişkin araştırmacı tarafindan geliştirilen Kişisel Bilgi Formu kullanılmış ayrıca araştırma verilerini oluşturmak amacıyla Tükenmişlik Ölçeği ve Psikolojik Dayanıklılık Ölçeği III-R kullanılmıştır. Verilerin normal dağılım göstermesinin anlaşılmasından sonra analizler; bağımsız t-testi, ANOVA ve Pearson Korelasyon testleri ile yapılmıştır. Analizler sonucunda psikolojik dayanıklılık ile tükenmişlik arasında negatif yönlü anlaml bir ilişki belirlenmiştir. Bununla birlikte psikolojik dayanıklilığın öğretmenlerde cinsiyet, medeni durum, branş, görev yapılan okul düzeyine göre farklılaşmadığ $ı$; yaş, kıdem, okuldaki hizmet süresine göre ise anlamlı farklılıklar tespit edilmiştir. Ayrıca tükenmişliğin öğretmenlerde cinsiyet, yaş, kıdem, branş, görev yapılan okul düzeyine göre farklılaştı̆̆ı; medeni duruma göre ise farklılaşmadığııı saptanmıştır.

Anahtar Kelimeler: Öğretmenler, Psikolojik Dayanıklılık, Tükenmişlik.

\footnotetext{
${ }^{1}$ Bu çalışma, Durmuş Bozkurt tarafından Doç. Dr. A. Faruk Levent danışmanlığında istanbul Sabahattin Zaim Üniversitesi, Lisansüstü Eğitim Enstitüsü, Eğitim Yönetimi Bilim Dalı’nda tamamlanan yüksek lisans tezinin bir bölümünden üretilmiştir.
} 


\title{
The Relationship between Teachers' Psychological Resilience and Burnout Levels
}

\begin{abstract}
The purpose of this study is to examine the relationship between teachers' psychological resilience and their burnout levels. The sample group of this study, in which the relational survey model, which is one of the quantitative research methods, was used, consists of 354 teachers selected by random simple random sampling method from a total of 4523 teachers working in public primary, secondary and high schools in Istanbul province Bağcllar district in the 2019-2020 academic year. Personal Information Form, Burnout Scale and Psychological Resilience Scale III-R regarding the demographic data of teachers were used as data collection tools. After the normal distribution of the data was understood, the analyzes were performed by independent t-test, ANOVA and Pearson Correlation tests. As a result of the analysis, a negative and significant relationship was determined between psychological resilience and burnout. On the other hand, psychological resilience of teachers does not differ according to gender, marital status, branch, school level; significant differences were determined according to age, seniority and length of service at school. In addition, burnout in teachers differs according to gender, age, seniority, branch, school level; it was found that there was no difference according to marital status.
\end{abstract}

Key Words: Teachers, Psychological Resilience, Burnout. 


\section{Giriş}

Hızla gelişen teknoloji, yaşam standartlarındaki olumlu-olumsuz değişimler ve rekabet ortamları, çalışanları her an birçok sorunla karşı karşıya getirmektedir. Çalışanların karşılaştıkları önemli sorunlardan biri de tükenmişliktir (Ergin, 1992). Tükenmişlik kelimesinin anlamı; "kuvvetini kaybetmiş olma, gayret göstermeme hali" biçiminde ifade edilmektedir (Türk Dil Kurumu, 2020).

Tükenmişlik; fizik, elektrik mühendisliği, havacılık, spor ve psikoloji gibi pek çok alanda kullanılan bir terimdir (Bährer-Kohler, 2013). İlk defa 1974 yılında Herbert Freudenberger tükenmişlik teriminin tanımını, "başarısız olma, hırpalanma, enerji ve kuvvet yitimi ya da giderilemeyen arzular neticesinde kişinin mevcut iç kaynaklarında tükenme" şeklinde yapmıştır (akt. Ardıç ve Polatçı, 2008). Maslach'a göre tükenmişlik "çalışma ortamında stresi artırıcı öğelere yönelik bir refleks olarak ortaya çıkan ruhsal bir sendrom" olarak açıklanmıştır (akt. Arı ve Bal, 2008). Pines'e (2002) göre ise tükenmişlik "duygusal ve fizyolojik isteklere yoğun olarak maruz kalmanın sebebiyet verdiği bedensel, duygusal ve zihinsel tükenme hali"dir.

Tükenmişlik ile ilgili yapılan araştırmalarda, bu sorunun kaynağı olarak birçok farklı boyuttan bahsedilmektedir. Cemaloğlu ve Şahin'e (2007) göre iş ortamları, yönetimler, yapılan işin özellikleri, iş yükünün, kadro yetersizlikleri, ekonomik yetersizlik, yaşanılan hayal kırıklıkları, enerjisinin tükendiğini hissetmesi, çalışanlar arasında tükenmişlik (burnout) sendromu olarak adlandirlan bir olguyu ortaya çıkarmaktadır. Tükenmişlik olgusu toplumsal yaşantının bir ürünü olarak hem çalışanların hayatını hem de örgütler açısından iş hayatını tehdit eden önemli bir sorun olarak görülmektedir (Arı ve Bal, 2008).

Hayatını iş odaklı olarak devam ettiren ve ağır iş yükü altında yaşamakta olan çalışanların tükenmeye maruz kalma ihtimalleri çok daha fazla olmaktadır (Maslach ve Goldberg, 1998). İnteraktif ilişkiyi zorunlu kılan meslek gruplarında istihdam edilen çalışanlar, tükenmişlik sendromunu daha fazla yaşayan kişilerdir (Ergin, 1996). Peker'e (2002) göre öğretmenler mesleki şartları ve okulda yoğun strese neden olacak unsurlar sebebiyle tükenmişlik açısından en yüksek riske sahip topluluktur. Bununla birlikte tükenmişlik, öğretmenlerin hem yöneticilerle ilişkilerini hem meslek arkadaşlarıyla ilişkilerini hem de 
öğrencilerle ilişkilerini etkileyen önemli bir olgu olarak karşımıza çıkmaktadır (Ergin, 1992). Tükenmişlik yaşayan öğretmenler, hem özel hayatında hem de iş hayatında problemler yaşamakta, öğrencilerle bağları kopmakta ve buna bağlı olarak da öğrencilerde motivasyon eksikliği ve davranış problemleri ortaya çıkmaktadır (Cemaloğlu ve Şahin, 2007; Dorman, 2003). Bu sebeple öğretmenlerde tükenmişlik ile ilgili daha fazla araştırmanın yapılması gerektiğine dikkat çekilmektedir (Budak ve Sürgevil, 2005; Oruç, 2007).

Dayanıklılık kelimesi, "çabuk iyileşme becerisi, zorluklarla baş etme gücü, elastikiyet" anlamlarını içermektedir (Demirbaş, 2010, s.2). Dayanıklılık, "şanssiz bir olay ya da değişimin ardından çabucak iyi olma ya da adapte olma becerisi" olarak da tanımlanmaktadır (Merriam Webster, 2020). Psikolojik dayanıklllık ise "yüksek riskli durumlara karşı iyi bir ilerleme kaydetme, strese maruz kalındığında dahi yetkinliğini devam ettirebilme, travmayı çabuk atlatabilme" olarak tanımlanmaktadır (Polatçı, Gültekin, Irk ve Sobacı, 2017).

Psikolojik dayanıklılık düzeyinin anksiyete, depresyon, intihar riski gibi durumlarla yakın ilişki içinde olduğu görülmektedir (Yöndem ve Bahtiyar, 2016). Güç durumlarla yüz yüze kalan ve buna karşın psikolojik anlamda hala kuvvetli kalan bireylerin psikolojik dayanıklılık düzeylerinin yüksek olduğu belirtilmektedir (Gürgan, 2006). Psikolojik dayanıklılığın; kişinin kendi performansı, sağlık durumu ve psikolojisi üzerine olumlu etkileri bulunmaktadır (Maddi ve Khoshaba, 1994). Ayrıca psikolojik dayanıklılığı yüksek olan bireyler, strese neden olan durumları daha hoş gören bir tutuma sahip olmaktadır (Maddi, Harvey, Khoshaba, Lu, Persico ve Brow, 2006).

Öğretmenlerin büyük bir bölümü, öğretmenliği yüksek düzeyde stresli bir meslek olarak nitelendirmektedir (Yalçın, 2013). Gelecek nesillerin yetiştirildiği okullarda, ortamın ve yapılan işin kendisinin stresli olması okulun en önemli insan kaynağı olan öğretmenlerin performanslarını önemli ölçüde etkilemektedir (Balay, 2000). Chan'a (2003) göre bir karakter özelliği olarak psikolojik dayanıklılık düzeyi yüksek öğretmenlerin tükenmişlik düzeyleri daha azdır ve bu öğretmenler stresli durumlarla daha kolay başa çıkabilirler (Yalçın, 2013). Sezgin (2009) tarafından yapılan araştırmada ise psikolojik 
dayanıklılı̆̆ı fazla olan öğretmenlerin içselleştirme ve özdeşleşme ile beraber örgütsel bağlılık düzeylerinin daha yüksek olduğu saptanmıştır.

Öğrencilerle bire bir iletişim kuran öğretmenler, öğrencilerine örnek teşkil etmekte ve öğretmenlerin psikolojik durumları doğrudan öğrencilerine yansımaktadır (Arıcan, 2009). Öğretmenin kendini yenilemede isteksiz olması; sınıf yönetiminde sorunlar yaşanmasına, öğrencilerde davranış problemlerinin ortaya çımasına, eğitimöğretimde verimin düşmesine ve mesleki tükenmişliklerin artmasına neden olabilmektedir (Demir Polat, 2018).

Literatür incelendiğinde öğretmenlerin psikolojik dayanıklılığı ile tükenmişlik düzeyleri arasındaki ilişkiyi inceleyen sınırlı sayıda çalışma olduğu görülmüştür. Bu bağlamda araştırmanın problem cümlesi "Öğretmenlerin psikolojik dayanıklılığı ile tükenmişlik düzeyleri arasında ilişki var mıdır?" şeklinde belirlenmiştir. Bu genel amaç doğrultusunda aşağıdaki sorulara yanıt aranmaya çalışılmıştır:

- Öğretmenlerin psikolojik dayanıklılık ve tükenmişlik düzeyleri nedir?

- Öğretmenlerin psikolojik dayanıklılık ve tükenmişlik düzeyleri, öğretmenlerin demografik özelliklerine (cinsiyet, medeni durum, branş, yaş, kıdem, okuldaki hizmet süresi ve okul türü) göre anlamlı farklılıklar göstermekte midir?

- Öğretmenlerin psikolojik dayanıklılığı ile tükenmişlik düzeyleri arasında anlamlı ilişkiler var mıdır?

\section{Yöntem}

\section{Araştırmanın Modeli}

Öğretmenlerin psikolojik dayanıklılık ile tükenmişlik düzeyleri arasındaki ilişkilerin incelenmesini amaçlayan bu çalışmada, nicel araştırma yöntemlerinden betimsel nitelik taşıyan ilişkisel tarama modeli kullanılmıştır. İlişkisel tarama modeli, iki veya daha çok değişken arasındaki birlikte değişimin varlığını ve değişim varsa bunun derecesini belirlemeyi amaçlayan araştırma modelidir (Karasar, 2012). Çalışmada bu model altında, öğretmenlerin psikolojik dayanıklılık ile tükenmişlik düzeyleri arasındaki açıklayıcı ve yordayıcı ilişkiler incelenmiştir. Ayrıca 
öğretmenlerin psikolojik dayanıklılık ile tükenmişlik düzeylerinin cinsiyet, medeni durum, yaş, branş, kıdem, okul türü ve okuldaki hizmet süresi gibi bazı değişkenlerine göre farklılıkları incelenmiştir.

\section{Çalışma Grubu}

Araştırmanın evrenini 2019-2020 eğitim-öğretim yılında İstanbul ili Bağcılar ilçesindeki resmi ilkokul, ortaokul ve liselerde görev yapan 4523 öğretmen oluşturmaktadır. Araştırmanın örneklemini ise bu evrenden seçkisiz basit tesadüfi örnekleme yöntemiyle belirlenen 354 öğretmen oluşturmaktadır. Araştırmanın evren ve çalışma grubuna ait sayısal veriler Tablo 1'de verilmiştir.

Tablo 1. Evren ve Çalışma Grubuna ait Öğretmen Sayıları

\begin{tabular}{lcc}
\hline Okul Türü & Evren & Çalışma Grubu \\
\hline İlkokul & 1687 & 120 \\
Ortaokul & 1593 & 120 \\
Lise & 1243 & 114 \\
Genel Toplam & 4523 & 354 \\
\hline
\end{tabular}

Araştırmanın çalışma grubunda bulunan öğretmenlerle ilgili demografik bilgiler Tablo 2'de verilmiştir.

Tablo 2. Örneklem Grubuna Ait Demografik Bilgiler, Frekans ve Yüzde Değerleri

\begin{tabular}{|c|c|c|c|c|c|}
\hline Cinsiyet & $\mathrm{f}$ & $\%$ & Branș & $\mathrm{f}$ & $\%$ \\
\hline Kadın & 193 & 54,5 & Sınıf Öğret. & 123 & 34,7 \\
\hline Erkek & 161 & 45,5 & Branş & 231 & 65,3 \\
\hline Toplam & 354 & 100 & Toplam & 354 & 100 \\
\hline Yaş & $\mathrm{f}$ & $\%$ & Mesleki Kıdem & $f$ & $\%$ \\
\hline $20-30$ & 85 & 24,0 & $1-5$ yil & 88 & 24,9 \\
\hline $31-35$ & 98 & 27,7 & $6-10$ yıl & 77 & 21,8 \\
\hline $36-40$ & 58 & 16,4 & $11-15 \mathrm{yll}$ & 67 & 18,9 \\
\hline $41-45$ & 57 & 16,1 & $16-20 \mathrm{yll}$ & 48 & 13,6 \\
\hline $46+$ & 56 & 15,8 & 21 yıl ve üzeri & 74 & 20,9 \\
\hline Toplam & 354 & 100 & Toplam & 354 & 100 \\
\hline Medeni Durum & $\mathrm{f}$ & $\%$ & Hizmet süresi & $\mathrm{f}$ & $\%$ \\
\hline$\overline{\text { Evli }}$ & 263 & 74,3 & $1-5$ yil & 215 & 60,7 \\
\hline Bekâr & 91 & 25,7 & $6-10$ & 81 & 22,9 \\
\hline Toplam & 354 & 100 & 11 yıl ve üzeri & 58 & 16,4 \\
\hline Okul türü & $\mathrm{f}$ & $\%$ & & & \\
\hline İlkokul & 120 & 33,9 & & & \\
\hline Ortaokul & 120 & 33,9 & & & \\
\hline Lise & 114 & 32,2 & & & \\
\hline Toplam & 354 & 100 & & & \\
\hline
\end{tabular}


Tablo 2'de katılımcıların \%54,5'inin erkek, \%45,5'inin kadın olduğu; katılımcıların görülmektedir. Katılımcıların \%24'ü 20-30 yaş arasındayken, \%27,7'si 31-35 yaş arasında, \%16,4'ü ise $36-40$ yaş arasında, \%16,1'i 41-45 yaş arasında ve \%15,8'i 46 yaş üzerindedir. Katılımcıların \%74,3'ü evli, \%25,7'si bekârdır. Katılımcıların \%24,9'u 1-5 yıl arasında, \%21,8'i 6-10 yıl arasinda, \%18,9'u 11-15 yıl arasında, $\% 13,6$ 'sı 16-20 yıl arasında ve \%20,9'u 21 yıl ve üzerinde mesleki kıdeme sahiptir. Katılımciların \%34,7'si sınıf öğretmeni, \%65,3'ü branş öğretmenidir. Katılımcıların \%60,7'si 1-5 yıl arasında, \%22,9'u 6-10 yıl arasinda ve \%16,4'ü 11 yıl ve üzerinde hizmet süresine sahiptir. Katılımcıların \%33,9'u ilkokulda, $\% 33,9^{\prime}$ u ortaokulda ve $\% 32,2^{\prime}$ si lisede görev yapmaktadır.

\section{Veri Toplama Aracı ve Verilerin Toplanması}

$\mathrm{Bu}$ araştırma için gerekli verilerin toplanması amacıyla Kişisel Bilgiler Formu, Tükenmişlik Ölçeği ve Psikolojik Dayanıklılık Ölçeği III-R kullanılmıştır. Her iki ölçeğin de izinleri önceden alınmış olup uygulama aşamasında gönüllülük ve gizlilik esasına dikkat edilmiştir. Öğretmenlere verilen Kişisel Bilgi Formu'nda cinsiyet, medeni durum, branş, yaş, kıdem, okuldaki hizmet yılı ve okul türü ile ilgili kişisel bilgilere yönelik yedi soru sorulmuştur.

Tükenmişlik Ölçeği (TÖ), Pines ve Aronson (1988) tarafından geliştirilmiş ve Çapri (2006) tarafından Türkçeye uyarlama çalışması yapılmıştır. TÖ'nün Pines ve Aronson tarafından yapılan güvenirlik çalışmaları incelendiğinde, iç tutarlık katsayısı .90, bir ve dört ay arayla uygulanan test tekrar güvenirlik katsayısı ise sırasıyla .88 ve .66 olarak görülmektedir. TÖ'nün yap1 geçerliği için yapılan faktör analizi sonucunda ölçeğin üç bileşenli ve tek faktörlü olduğu ifade edilmiştir (Pines ve Aronson, 1988). Ölçek maddeleri "1 = Hiçbir zaman" ve “7 = Her zaman" biçiminde puanlanmaktadır. Ölçekten alınabilecek en yüksek puan ' 7 ', en düşük puan ise ' 1 'dir. Ölçek puanı hesaplamasında olumlu maddeler $(3,6,19$ ve 20) ters, diğer maddeler düz puanlanmaktadır. Ölçekten alınan puan yorumlanırken dört düzey kullanılmaktadır. Ölçekten alınan 3 ve altındaki puanlar tükenmişlik 
durumu olmadığı, 3-4 arasındaki puanlar tükenmişlik için bir tehdit olabileceği, $4-5$ arasındaki puanlar tükenmişlik yaşandığı, 5 ve üzeri puanlar yardım gerektiren bir tükenmişlik durumu olduğu biçiminde yorumlanmaktadır. Çapri'nin (2006) 876 katılımcıyla gerçekleştirdiği uyarlama çalışmasında, temel bileşenler faktör analizinde KMO değeri .96 olarak bulunmuştur. Uyarlama çalışmasında ölçeğin iç tutarlık katsayısı .93, alt bileşenler için sırasıyla $.83, .75$ ve .88 olarak bulunmuştur. Ölçeğin iki ay arayla test tekrar test yöntemiyle elde edilen korelasyon katsayısı ise .83 olarak hesaplanmıştır (Çapri, 2006). Bu ölçek, Maddi ve Khoshaba (2001) tarafından geliştirilmiş, çok maddeli hali Motan (2002), kısa versiyonunun Türkçeye uyarlama çalışması Durak (2002) tarafından yapılmıştır. Ölçek, bireyin kendisine ve yaşamına ilişkin inançlarını ifade eden 18 maddenin temsil ettiği bağlanma, kontrol ve güçlük olmak üzere üç alt boyuttan oluşmaktadır. Her boyut, üç olumlu üç olumsuz anahtar kelimeyle şekillendirilmiş toplam altı maddeyle ölçülmektedir. Ölçeğin iç tutarlık katsayısı .80, alt boyutların iç tutarlığ 1 ise .71 olarak hesaplanmıştır (Maddi ve diğerleri, 2006). Likert tipinde ve 0-3 arasında puanlanan bir ölçektir. Ölçek maddeleri “ $0=$ Hiç doğru değil" ve " $3=$ Çok doğru" şeklinde derecelendirilmiştir. Ölçekten alınan puanların yüksekliği psikolojik dayanıklılığın arttığını, düşüklüğü ise dayanıklılığın azaldığını göstermektedir. Ölçeğin geçerlik ve güvenirlik çalışmalarında altı maddenin madde toplam korelasyonları .20'nin altında çıktığı için bu maddeler ölçekten atılmıştır. Geri kalan 12 maddenin madde toplam korelasyonları .23 ile .50 arasında olmuş ve ölçeğin iç tutarlık katsayısı .68 bulunmuştur (Durak, 2002).

\section{Etik Kurul Raporu}

İstanbul Sabahattin Zaim Üniversitesi Sosyal Bilimler Enstitüsü Araştırma ve Yayın Etik Kurulu, 26.02.2020 tarihinde 2020/02 onay sayılı kararı ile bu araştırmanın etik yönden uygun olduğuna karar vermiş ve 20292139-050.01.04 sayılı evrak ile etik kurul onayını bildirmiştir. 


\section{Verilerin Analizi}

Toplanan veriler analiz edilmek üzere bilgisayar ortamına aktarılmıştır. Verilerin analizinde SPSS 25.0 programı kullanılmıştır. Değişkenler arası ilişkilerin belirlenmesi için Pearson Momentler Çarpımı Korelasyon Katsayısı, yordayıcı değişkenlerin incelenmesinde Çoklu Doğrusal Regresyon Analizi, öğretmenlerin görüşlerinin cinsiyet, medeni durum, yaş, branş, kıdem ve okuldaki hizmet süresi gibi demografik değişkenlere göre farklılığının analizinde ise t-testi ve ANOVA kullanılmıştır.

\section{Bulgular}

Araştırmaya katılan öğretmenlerin verdikleri cevaplara göre psikolojik dayanıklılık ile tükenmişlik değişkeninin alt boyutlarına ilişkin betimsel analiz sonuçları Tablo 3'te yer almaktadır.

Tablo 3. Psikolojik Dayanıklılık Ölçeği ile Tükenmişlik Ölçeği Alt Boyutları Değişkenlerine İlişkin Analiz Sonuçları

\begin{tabular}{lccccc}
\hline & $\mathbf{N}$ & Min. & Maks. & Ort. & SS \\
\hline Psikolojik dayanıklılık & 354 &, 31 & 3,00 & 2,08 &, 48 \\
\hline Tükenmişlik & & & & & \\
\hline Duygusal tükenme & 354 & 1,00 & 6,14 & 2,84 & 1,09 \\
Zihinsel tükenme & 354 & 1,00 & 5,71 & 2,49 &, 94 \\
Fiziksel tükenme & 354 & 1,00 & 5,86 & 3,03 & 1,07 \\
\hline
\end{tabular}

Tablo 3 'te görüldüğü üzere yapılan betimsel analiz sonucunda

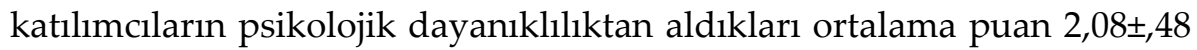
olarak bulunurken, Tükenmişlik Ölçeği'nin duygusal tükenme boyutundan aldıkları ortalama puan 2,84 $\pm 1,09$ olarak, zihinsel tükenme

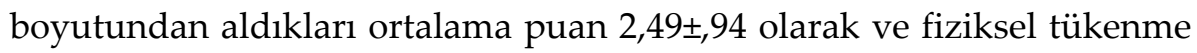
boyutundan aldıkları ortalama puan 3,03 1,07 olarak bulunmuştur.

Psikolojik dayanıklılık değişkeni ile tükenmişlik değişkeni alt boyutları arasındaki ilişkiye yönelik Pearson Korelasyon analizi sonuçları Tablo 4 'te yer almaktadır. 
Tablo 4. Psikolojik Dayanıklılık ile Tükenmişlik Ölçeği Alt Boyutları Değişkenlerine İlişkin Pearson Korelasyon Analizi Sonuçları

\begin{tabular}{lcc}
\hline & & \multicolumn{1}{c}{ Psikolojik dayanıklılık } \\
\hline \multirow{2}{*}{ Duygusal tükenme } & $\mathrm{R}$ &,- 647 \\
\cline { 2 - 3 } Zihinsel tükenme & $\mathrm{P}$ &, $000^{*}$ \\
\hline \multirow{2}{*}{ Fiziksel tükenme } & $\mathrm{R}$ &,- 621 \\
\cline { 2 - 3 } & $\mathrm{P}$ & $000^{*}$ \\
\cline { 2 - 3 } & $\mathrm{R}$ &,- 729 \\
\hline
\end{tabular}

${ }^{*} p<, 01$

Tablo 4'te görüldügü üzere yapılan Pearson korelasyon analizi sonuçlarına göre psikolojik dayanıklılık ile duygusal tükenme, zihinsel tükenme ve fiziksel tükenme arasında negatif yönlü ve anlamlı ilişki bulunmuştur (r=-,647, -,621, -,729, p<,01). Buna göre psikolojik dayanıklılık arttığında tükenmişlik düzeylerinin azaldığı görülmektedir.

Katılımcı öğretmenlerin cinsiyeti ile psikolojik dayanıklılık ve tükenmişlik değişkeni alt boyutları arasındaki ilişkiyi bulmaya yönelik yapılan Bağımsız Örneklem t Testi sonuçları Tablo 5'te yer almaktadır.

Tablo 5. Cinsiyete Göre Araştırma Değişkenleri Arasındaki İlişkiye Yönelik Bă̆ımsız Örneklem t Testi Sonuçları

\begin{tabular}{|c|c|c|c|c|c|c|}
\hline & Cinsiyet & $\mathbf{N}$ & Ort. & SS & $t$ & $\mathbf{P}$ \\
\hline \multirow{2}{*}{ Psikolojik dayanıklılık } & Erkek & 161 & 2,03 &, 54 & \multirow{2}{*}{$-1,762$} & \multirow{2}{*}{, 079} \\
\hline & Kadın & 193 & 2,12 &, 41 & & \\
\hline \multirow{2}{*}{ Duygusal tükenme } & Erkek & 161 & 2,72 & 1,07 & \multirow{2}{*}{$-1,942$} & \multirow{2}{*}{, 053} \\
\hline & Kadın & 193 & 2,94 & 1,10 & & \\
\hline \multirow{2}{*}{ Zihinsel tükenme } & Erkek & 161 & 2,38 &, 94 & \multirow{2}{*}{$-1,971$} & \multirow{2}{*}{, $049^{*}$} \\
\hline & Kadın & 193 & 2,58 & ,94 & & \\
\hline \multirow{2}{*}{ Fiziksel tükenme } & Erkek & 161 & 2,98 & 1,15 & \multirow{2}{*}{,- 695} & \multirow{2}{*}{,487 } \\
\hline & Kadın & 193 & 3,06 & ,99 & & \\
\hline
\end{tabular}

Tablo 5'te görüldüğü üzere yapılan bağımsız örneklem $\mathrm{t}$ testi sonucunda psikolojik dayanıklılık, duygusal tükenme ve fiziksel tükenmenin katılımcıların cinsiyetlerine göre anlamlı bir şekilde

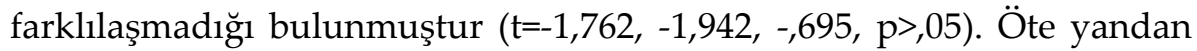
zihinsel tükenmenin katılımcıların cinsiyetlerine göre anlamlı farklılık gösterdiği tespit edilmiştir ( $\mathrm{t}=-1,971, \mathrm{p}<, 05)$. Buna göre kadınların zihinsel tükenme düzeyinin erkeklere göre daha fazla olduğu söylenebilir. 
Öğretmenlerin yaşı ile psikolojik dayanıklılık değişkeni ve tükenmişlik değişkeni alt boyutları arasındaki ilişkiyi bulmak için tek yönlü varyans analizi sonuçları Tablo 6'da yer almaktadır.

Tablo 6. Yaşa Göre Araştırma Değişkenleri Arasındaki İlişkiye Yönelik Tek Yönlü Varyans Analizi Sonuçları

\begin{tabular}{|c|c|c|c|c|c|c|}
\hline & Yaş & $\mathbf{N}$ & Ort. & SS & $\mathbf{F}$ & $\mathbf{P}$ \\
\hline \multirow{5}{*}{$\begin{array}{l}\text { Psikolojik } \\
\text { dayanıklılık }\end{array}$} & $20-30$ yaş arası & 85 & 2,26 & 43 & \multirow{5}{*}{14,833} & \multirow{5}{*}{, $000^{*}$} \\
\hline & 31-35 yaş arası & 98 & 2,04 &, 41 & & \\
\hline & $36-40$ yaş arası & 58 & 1,72 & 62 & & \\
\hline & 41-45 yaş arası & 57 & 2,14 & ,38 & & \\
\hline & 46 yaş ve üzeri & 56 & 2,21 & 34 & & \\
\hline \multirow{5}{*}{ Duygusal tükenme } & 20-30 yaş arası & 85 & 2,82 & 1,30 & \multirow{5}{*}{6,855} & \multirow{5}{*}{, $000^{*}$} \\
\hline & 31-35 yaş arası & 98 & 3,04 & 1,18 & & \\
\hline & $36-40$ yaş arası & 58 & 3,19 &, 83 & & \\
\hline & 41-45 yaş arası & 57 & 2,75 & ,74 & & \\
\hline & 46 yaş ve üzeri & 56 & 2,26 & 88 & & \\
\hline \multirow{5}{*}{ Zihinsel tükenme } & 20-30 yaş arası & 85 & 2,55 & 1,12 & \multirow{5}{*}{5,169} & \multirow{5}{*}{, $000^{*}$} \\
\hline & 31-35 yaş arası & 98 & 2,71 & 1,03 & & \\
\hline & $36-40$ yaş arası & 58 & 2,64 & 63 & & \\
\hline & 41-45 yaş arası & 57 & 2,20 & 64 & & \\
\hline & 46 yaş ve üzeri & 56 & 2,15 & 87 & & \\
\hline \multirow{5}{*}{ Fiziksel tükenme } & 20-30 yaş arası & 85 & 2,93 & 1,24 & \multirow{5}{*}{5,603} & \multirow{5}{*}{, $000^{*}$} \\
\hline & 31-35 yaş arası & 98 & 3,07 & 1,01 & & \\
\hline & $36-40$ yaş arası & 58 & 3,50 & 86 & & \\
\hline & 41-45 yaş arası & 57 & 3,02 & 83 & & \\
\hline & 46 yaş ve üzeri & 56 & 2,60 & 1,12 & & \\
\hline
\end{tabular}

${ }^{*} p<, 01$

Tablo 6'da görüldüğü üzere, yapılan tek yönlü varyans analizi sonuçlarına göre psikolojik dayanıklılık, duygusal tükenme, zihinsel tükenme ve fiziksel tükenmenin yaşa göre anlamlı farklılıklar gösterdiği bulunmuştur $(\mathrm{F}(4,349)=14,833,6,855,5,169,5,603, \mathrm{p}<, 01)$. Bulunan anlamlı farklılıkların hangi yaş grupları arasında olduğunu tespit edebilmek amacıyla Bonferroni Post-hoc testi yapılmıştır. Buna göre 3640 yaş arası bireylerin psikolojik dayanıklılıklarının diğer tüm yaş gruplarından anlamlı bir şekilde daha az olduğu bulunmuştur. Ayrıca 20-30 yaş arası bireylerin psikolojik dayanıklılığının 31-35 yaş arası bireylere göre anlamlı bir şekilde daha fazla olduğu tespit edilmiştir. Öte yandan 46 yaş ve üzeri bireylerin duygusal tükenme durumunun, 20-40 yaş arası bireylerden anlamlı bir şekilde daha az olduğu saptanmıştır. Bunun yanı sıra 31-35 yaş arası bireylerin zihinsel tükenme durumunun, 
41 yaş üzeri bireylerden anlamlı bir şekilde daha fazla olduğu bulunmuştur. Ayrıca 36-40 yaş arası bireylerin zihinsel tükenme durumunun da 46 yaş ve üzeri bireylerden anlamlı bir şekilde daha fazla olduğu belirlenmiştir. Son olarak 36-40 yaş arası bireylerin fiziksel tükenme durumunun, $20-30$ yaş arası ve 46 yaş ve üzeri bireylerden anlamlı bir şekilde daha fazla olduğu bulunmuştur.

Medeni durum ile psikolojik dayanıklılık değişkeni ve tükenmişlik değişkeni alt boyutları arasındaki ilişkiye yönelik yapılan bağımsız örneklem $\mathrm{t}$ testi sonuçları Tablo 7'de yer almaktadır.

Tablo 7. Medeni Duruma Göre Araştırma Değişkenleri Arasındaki İlişkiye Yönelik Bă̆ımsız Örneklem t Testi Sonuçları

\begin{tabular}{|c|c|c|c|c|c|c|}
\hline & Medeni durum & $\mathbf{N}$ & Ort. & SS & $t$ & $\mathbf{P}$ \\
\hline \multirow{2}{*}{ Psikolojik dayanıklılık } & Evli & 263 & 2,08 & 45 & \multirow[b]{2}{*}{,- 272} & \multirow{2}{*}{,786 } \\
\hline & Bekâr & 91 & 2,09 &, 55 & & \\
\hline \multirow{2}{*}{ Duygusal tükenme } & Evli & 263 & 2,82 & 1,11 & \multirow{2}{*}{,- 668} & \multirow{2}{*}{,505 } \\
\hline & Bekâr & 91 & 2,91 & 1,03 & & \\
\hline \multirow{2}{*}{ Zihinsel tükenme } & Evli & 263 & 2,48 & ,97 & \multirow{2}{*}{,- 464} & \multirow{2}{*}{643} \\
\hline & Bekâr & 91 & 2,53 &, 86 & & \\
\hline \multirow{2}{*}{ Fiziksel tükenme } & Evli & 263 & 3,01 & 1,09 & \multirow{2}{*}{,- 567} & \multirow{2}{*}{, 571} \\
\hline & Bekâr & 91 & 3,08 & 1,00 & & \\
\hline
\end{tabular}

Tablo 7'de görüldüğü üzere yapılan bağımsız örneklem t testi sonucunda psikolojik dayanıklılık, duygusal tükenme, zihinsel tükenme ve fiziksel tükenmenin katılımcıların medeni durumuna göre anlamlı bir şekilde farklılaşmadığı bulunmuştur (Sirasıyla $\mathrm{t}=-, 272,-, 668,-, 464,-, 567$, $\mathrm{p}>, 05)$.

Katılımcı öğretmenlerin mesleki kıdemi ile psikolojik dayanıklılık ve tükenmişlik değişkeni alt boyutları arasındaki ilişkiyi tespit etmeye yönelik tek yönlü varyans analiz sonuçları Tablo 8 ' de yer almaktadır.

Tablo 8. Mesleki Kıdeme Göre Araştırma Değişkenleri Arasındaki İlişkiye Yönelik Tek Yönlü Varyans Analizi Sonuçlam

\begin{tabular}{|c|c|c|c|c|c|c|}
\hline & Mesleki kıdem & $\mathbf{N}$ & Ort. & SS & $\mathbf{F}$ & $\mathbf{P}$ \\
\hline \multirow{5}{*}{$\begin{array}{l}\text { Psikolojik } \\
\text { dayanıklılık }\end{array}$} & $1-5$ yil & 88 & 2,13 &, 45 & \multirow{5}{*}{10,369} & \multirow{5}{*}{, $000^{*}$} \\
\hline & 6-10 yil & 77 & 2,27 &, 38 & & \\
\hline & $11-15$ yıl & 67 & 1,90 &, 49 & & \\
\hline & $16-20$ yil & 48 & 1,83 &, 60 & & \\
\hline & 21 yıl ve üzeri & 74 & 2,15 & ,37 & & \\
\hline \multirow{2}{*}{$\begin{array}{l}\text { Duygusal } \\
\text { tükenme }\end{array}$} & $1-5$ yil & 88 & 2,74 & 1,06 & \multirow{2}{*}{6,779} & \multirow{2}{*}{, $000^{*}$} \\
\hline & 6-10 yil & 77 & 2,93 & 1,13 & & \\
\hline
\end{tabular}




\begin{tabular}{|c|c|c|c|c|c|c|}
\hline & $11-15$ yil & 67 & 3,12 & 1,22 & & \\
\hline & $16-20$ yıl & 48 & 3,21 & ,93 & & \\
\hline & 21 yıl ve üzeri & 74 & 2,37 & 85 & & \\
\hline \multirow{5}{*}{ Zihinsel tükenme } & $1-5$ yil & 88 & 2,57 & 84 & \multirow{5}{*}{4,429} & \multirow{5}{*}{, $002^{*}$} \\
\hline & 6-10 yıl & 77 & 2,51 & 1,03 & & \\
\hline & $11-15$ yıl & 67 & 2,71 & 1,00 & & \\
\hline & $16-20$ yıl & 48 & 2,59 & ,95 & & \\
\hline & 21 yıl ve üzeri & 74 & 2,11 & ,78 & & \\
\hline \multirow{5}{*}{ Fiziksel tükenme } & $1-5$ yil & 88 & 2,84 & ,93 & \multirow{5}{*}{7,392} & \multirow{5}{*}{, $000^{*}$} \\
\hline & 6-10 y1l & 77 & 2,99 & 1,13 & & \\
\hline & $11-15$ yıl & 67 & 3,36 & ,93 & & \\
\hline & $16-20$ yıl & 48 & 3,51 & 1,14 & & \\
\hline & 21 yıl ve üzeri & 74 & 2,67 & 1,05 & & \\
\hline
\end{tabular}

${ }^{*} p<, 01$

Tablo 8'de görüldüğ̈̈ üzere yapılan tek yönlü varyans analizi sonuçlarına göre psikolojik dayanıklılık, duygusal tükenme, zihinsel tükenme ve fiziksel tükenmenin mesleki kıdeme göre anlamlı farklılıklar gösterdiği bulunmuştur; bunlar sirasıyla $\mathrm{F}(4,349)=10,369$, 6,779, 4,429, $7,392, \mathrm{p}<, 01$. Bulunan anlamlı farkl1lkların hangi kıdem grupları arasında olduğunu tespit edebilmek amaciyla Bonferroni Post-hoc testi yapılmıştır. Buna göre mesleki kıdemi 21 yıl ve üzeri olan ve 1-5 yıl arası olan bireylerin psikolojik dayanıkl1lklarının 11-20 yıl kıdemi olanlara göre anlamlı bir şekilde daha fazla olduğu belirlenmiştir. Bununla birlikte 6-10 yıl arası kıdemi olan bireylerin duygusal tükenme durumunun, 11-20 yıl arası kıdemi olan bireylerden anlamlı bir şekilde daha fazla olduğu tespit edilmiştir. Mesleki kıdemi 21 yıl ve üzeri olan bireylerin ise duygusal tükenme durumunun, kıdemi 6-20 yıl arası olan bireylerden anlamlı bir şekilde daha az olduğu bulunmuştur. Benzer şekilde mesleki kıdemi 21 yıl ve üzeri olan bireylerin zihinsel tükenme durumunun ise, 20 yıldan az kıdemi olan bireylerden anlamlı bir şekilde daha az olduğu bulunmuştur. Mesleki kıdemi 11-20 yıl arasında olan bireylerin fiziksel tükenme durumunun, kıdemi 1-5 yıl arasında olan ve 21 yıl üzerinde olan bireylerden anlamlı bir şekilde daha fazla olduğu saptanmiştır.

Katılımcı öğretmenlerin branşı ile psikolojik dayanıklılık ve tükenmişlik değişkeni alt boyutları arasındaki ilişkiyi bulmaya yönelik yapılan bağımsız örneklem $t$ testi sonuçları Tablo 9'da yer almaktadır. 
Tablo 9. Branşa Göre Araştırma Değişkenleri Arasındaki İlişkiye Yönelik Bağımsız Örneklem $t$ Testi Sonuçları

\begin{tabular}{|c|c|c|c|c|c|c|}
\hline & Branş & $\mathbf{N}$ & Ort. & SS & $t$ & $\mathbf{P}$ \\
\hline \multirow{2}{*}{ Psikolojik dayanıklılık } & Sınıf öğretmeni & 123 & 2,05 & ,63 & \multirow{2}{*}{$-1,051$} & \multirow{2}{*}{,294 } \\
\hline & Branş öğretmeni & 231 & 2,10 &, 37 & & \\
\hline \multirow{2}{*}{ Duygusal tükenme } & $\underline{\text { Sınıf öğretmeni }}$ & 123 & 2,69 & 1,08 & \multirow{2}{*}{$-1,876$} & \multirow{2}{*}{, 062} \\
\hline & Branş öğretmeni & 231 & 2,92 & 1,08 & & \\
\hline \multirow{2}{*}{ Zihinsel tükenme } & $\underline{\text { Sınıf öğretmeni }}$ & 123 & 2,29 &, 89 & \multirow{2}{*}{$-3,018$} & \multirow{2}{*}{, $003^{*}$} \\
\hline & Branş öğretmeni & 231 & 2,60 & ,95 & & \\
\hline \multirow{2}{*}{ Fiziksel tükenme } & $\underline{\text { Sınıf öğretmeni }}$ & 123 & 2,99 & 1,18 & \multirow{2}{*}{,- 476} & \multirow{2}{*}{,634 } \\
\hline & Branş öğretmeni & 231 & 3,05 & 1,00 & & \\
\hline
\end{tabular}

${ }^{*} p<, 01$

Tablo 9'da görüldüğü üzere yapılan bağımsız örneklem $t$ testi sonucunda psikolojik dayanıklılık, duygusal tükenme ve fizikse tükenmenin katılımcıların branşına göre anlamlı bir şekilde farklılaşmadığı görülmüştür. Sırasıyla $t=-1,051,-1,876,-, 476, p>, 05$. Öte yandan zihinsel tükenmenin katılımcıların branşına göre anlamlı bir şekilde farklılaştığ1 bulunmuştur, $t=-3,018, p<, 01$. Buna göre branş öğretmenlerinin zihinsel tükenme düzeyi sınıf öğretmenlerine kıyasla daha yüksektir.

Okuldaki hizmet süresi ile psikolojik dayanıklılık ve tükenmişlik değişkeni alt boyutları arasındaki ilişkiye yönelik tek yönlü varyans analizi sonuçları Tablo 10' da yer almaktadır.

Tablo 10. Okuldaki Hizmet Süresine Göre Araştırma Değişkenleri Arastndaki İlişkiye Yönelik Tek Yönlï Varyans Analizi Sonuçları

\begin{tabular}{|c|c|c|c|c|c|c|}
\hline & $\begin{array}{l}\text { Okuldaki hizmet } \\
\text { süresi }\end{array}$ & $\mathbf{N}$ & Ort. & SS & $\mathbf{F}$ & $\mathbf{P}$ \\
\hline & $1-5 \mathrm{yll}$ & 215 & 2,18 & 41 & \multirow{3}{*}{$-11,575$} & \multirow{3}{*}{, $000^{*}$} \\
\hline \multirow[t]{3}{*}{ Psikolojik dayanıklılık } & $6-10$ & 81 & 1,90 & 49 & & \\
\hline & 11 yıl ve üzeri & 58 & 1,99 & ,59 & & \\
\hline & $1-5$ yil & 215 & 2,71 & 1,03 & \multirow{3}{*}{6,187} & \multirow{3}{*}{, $002^{*}$} \\
\hline \multirow[t]{3}{*}{ Duygusal tükenme } & $6-10$ & 81 & 3,20 & 1,25 & & \\
\hline & 11 yıl ve üzeri & 58 & 2,82 & 95 & & \\
\hline & $1-5$ yıl & 215 & 2,40 & 90 & \multirow{3}{*}{3,095} & \multirow{3}{*}{, $047^{*}$} \\
\hline \multirow[t]{3}{*}{ Zihinsel tükenme } & $6-10$ & 81 & 2,70 & 1,12 & & \\
\hline & 11 yıl ve üzeri & 58 & 2,53 & 78 & & \\
\hline & $1-5 \mathrm{yll}$ & 215 & 2,83 & 96 & \multirow{3}{*}{9,865} & \multirow{3}{*}{, $000^{*}$} \\
\hline \multirow[t]{2}{*}{ Fiziksel tükenme } & $6-10$ & 81 & 3,39 & 1,13 & & \\
\hline & 11 yıl ve üzeri & 58 & 3,24 & 1,19 & & \\
\hline
\end{tabular}

${ }^{*} p<, 05$ 
Tablo 10'da görüldüğü üzere, yapılan tek yönlü varyans analizi sonuçlarına göre psikolojik dayanıklılık, duygusal tükenme, zihinsel tükenme ve fiziksel tükenmenin okuldaki hizmet süresine göre anlamlı farklılıklar gösterdiği bulunmuştur, bunlar sırasıyla $F(2,351)=11,575$, 6,187, 3,095, 9,865, p<,05. Bulunan anlamlı farklılıkların hangi gruplar arasında olduğunu tespit edebilmek amaciyla Bonferroni Post-hoc testi yapılmıştır. Buna göre hizmet süresi 1-5 yıl arası olan bireylerin psikolojik dayanıklılıklarının 6 yıl ve üzeri hizmet süresi olanlara göre anlamlı bir şekilde daha fazla olduğu bulunmuştur. Bunun yanı sıra hizmet süresi 6-10 yıl arası olan bireylerin duygusal ve zihinsel tükenme durumlarının 1-5 yıl hizmet süresi olanlara göre anlamlı bir şekilde daha fazla olduğu saptanmıştır. Hizmet süresi 1-5 yıl arası olan bireylerin fiziksel tükenme durumunun ise hizmet süresi 6 yıl ve üzerinde olan bireylerden anlamlı bir şekilde daha az olduğu tespit edilmiştir.

Araştırmadan elde edilen görev yapılan okul ile psikolojik dayanıklılık ve tükenmişlik değişkeni alt boyutları arasındaki ilişkiye yönelik tek yönlü varyans analiz sonuçları Tablo 11'de gösterilmektedir.

Tablo 11. Görev Yapılan Okul ile Araştırma Değişkenleri Arasındaki İlişkiye Yönelik Tek Yönlü Varyans Analizi Sonuçları

\begin{tabular}{|c|c|c|c|c|c|c|}
\hline & Görev yapılan okul & $\mathbf{N}$ & Ort. & SS & F & $\mathbf{P}$ \\
\hline \multirow{3}{*}{ Psikolojik dayanıklılık } & İlkokul & 120 & 2,04 & ,64 & \multirow{3}{*}{1,259} & \multirow{3}{*}{,285 } \\
\hline & Ortaokul & 120 & 2,14 & 34 & & \\
\hline & Lise & 114 & 2,07 & 40 & & \\
\hline \multirow{3}{*}{ Duygusal tükenme } & İlkokul & 120 & 2,64 & ,99 & \multirow{3}{*}{5,555} & \multirow{3}{*}{, $009^{*}$} \\
\hline & Ortaokul & 120 & 3,07 & 1,14 & & \\
\hline & Lise & 114 & 2,82 & 1,09 & & \\
\hline \multirow{3}{*}{ Zihinsel tükenme } & İlkokul & 120 & 2,21 & ,77 & \multirow{3}{*}{7,997} & \multirow{3}{*}{, $000^{*}$} \\
\hline & Ortaokul & 120 & 2,73 & ,95 & & \\
\hline & Lise & 114 & 2,53 & 1,03 & & \\
\hline \multirow{3}{*}{ Fiziksel tükenme } & İlkokul & 120 & 2,95 & 1,12 & \multirow{3}{*}{1,369} & \multirow{3}{*}{,301 } \\
\hline & Ortaokul & 120 & 3,15 & 1,00 & & \\
\hline & Lise & 114 & 2,97 & 1,07 & & \\
\hline
\end{tabular}

${ }^{*} p<, 01$ 
Tablo 11'de görüldüğü üzere yapılan tek yönlü varyans analizi sonuçlarına göre psikolojik dayanıklılık ve fiziksel tükenmenin görev yapılan okullara göre anlamlı farklılıklar göstermediği bulunmuştur. Sırasıyla $F(2,351)=1,259,1,369, p>, 05$. Öte yandan duygusal tükenme ve zihinsel tükenmenin görev yapılan okullara göre anlamlı farklılıklar gösterdiği tespit edilmiştir. Sırasıyla $\mathrm{F}(2,351)=5,555,7,997, \mathrm{p}<, 01 . \mathrm{Bu}$ anlamlı farklılıkların hangi gruplar arasında olduğunu tespit edebilmek amacıyla Bonferroni Post-hoc testi yapılmış ve ortaokulda görev yapan öğretmenlerin duygusal tükenme durumlarının ilkokulda görev yapanlara göre anlamlı bir şekilde daha fazla olduğu bulunmuştur. Öte yandan ilkokulda görev yapan öğretmenlerin zihinsel tükenme durumunun ortaokulda ve lisede görev yapan bireylere göre anlamlı bir şekilde daha az olduğu saptanmıştır.

\section{Tartışma}

Öğretmenlerin psikolojik dayanıklılığı ile tükenmişlik düzeyleri arasındaki ilişkinin incelendiği bu araştırmada öğretmenlerin tükenmişlik düzeylerinin; duygusal tükenme, zihinsel tükenme ve fiziksel tükenme alt boyutlarıla beraber; ortalama düzeyde olduğu tespit edilmiştir. Araştırmada elde edilen bulgulara göre toplam psikolojik dayanıklılık puanının ise ortalamanın üzerinde olduğu saptanmıştır. Psikolojik dayanıklılık ile demografik değişkenler arasındaki ilişkiler incelendiğinde psikolojik dayanıklılık ile cinsiyet, medeni durum, branş ve okul türü arasında anlamlı bir farklılık bulunmazken; yaş, mesleki kıdem ve okuldaki hizmet süresi değişkenleri arasında anlamlı farklılıklar bulunmaktadır. Tükenmişlik ile demografik değişkenler arasındaki ilişkiler incelendiğinde tükenmişlik ile medeni durum arasında anlamlı bir farklılık bulunmazken; tükenmişlik ile cinsiyet, yaş, kıdem, branş, okuldaki hizmet süresi ve görev yaptığı okul türü değişkenleri arasında anlamlı farklılıklar bulunmaktadır. Psikolojik dayanıklılık ile tükenmişlik arasındaki ilişki incelendiğinde psikolojik dayanıklılık ile tükenmişlik alt boyutları olan duygusal tükenme, zihinsel tükenme ve fiziksel tükenme arasında negatif yönlü ve anlamlı ilişki tespit edilmiştir. 
$\mathrm{Bu}$ araştırmada; toplam tükenmişlik düzeyinde, öğretmenlerin tükenmişlik algılarının orta düzeyde olduğu belirlenmiştir. Bu bulgu, literatürde yapılmış bazı araştırma sonuçlarıyla benzerlik göstermektedir. Örneğin Hock (1998) yaptığı çalışmada öğretmenlerin yaklaşık \%41'inin orta ve yüksek derecede tükenmişlik yaşadığı tespit edilmiştir (akt. Aslan, 2009). Buna karşın Arıcan (2009), öğretmenlerin tükenmişlik algılarının ortalama puanlarının düşük olduğu sonucuna ulaşmıştır.

$\mathrm{Bu}$ araştırmada toplam psikolojik dayanıklılık puanının ortalamanın üzerinde olduğu tespit edilmiştir. Literatürde benzer sonuçlara ulaşılan araştırmalar mevcuttur. Örneğin Uçar (2014), özel eğitim öğretmenleriyle yaptığı araştırmasında, öğretmenlerin algılarına göre psikolojik dayanıklılık düzeylerinin yüksek olduğu sonucuna ulaşmıştır. Yalçın (2013) ise ilköğretim okulu öğretmenlerini örneklem olarak aldığ1 araştırmasında öğretmenlerin psikolojik dayanıklılık algı düzeylerinin yüksek düzeyde olduğu sonucuna ulaşmıştır. Her meslekte, çalışanların psikolojik dayanıklılıklarının yüksek olması olumlu değerlendirilmektedir. Psikolojik dayanıklılığın yüksek olmasıyla öğretmenlerin meslekî yaşamlarında güçlüklerle karşılaştıklarında, başa çıkma becerilerini kullanarak güçlüklerin üstesinden gelebilecekleri umut edilmektedir. Psikolojik dayanıklılık bir kişilik özelliği olarak düşünüldüğünde; öğretmenlerin genel tükenmişlik düzeylerinin orta düzeyde olması, meslekî tükenmişliğin örgütsel faktörlerden kaynaklanabileceği düşünülebilir.

Psikolojik dayanıklılık ile demografik değişkenler arasındaki ilişkiler incelendiğinde psikolojik dayanıklılık ile cinsiyet, medeni durum, branş ve okul türü arasında anlamlı bir farklılık bulunmazken; yaş, mesleki kıdem ve okuldaki hizmet süresi değişkenleri arasında anlamlı farklılıklar bulunmaktadır. Öğretmenlerin cinsiyetleri ile psikolojik dayanıklılık düzeyleri incelendiğinde, cinsiyet değişkeni ile psikolojik dayanıklılık değişkeni arasında anlamlı bir farklılık olmadığı sonucuna ulaşılmıştır. Literatür incelendiğinde bu bulguyu destekler nitelikte birçok çalışma olduğu görülmektedir (Yalçın, 2013; Gökmen, 2014; Sönmezer, 2015; Karataş, 2016; Kaya, 2018; Ülker-Tümlü ve Recepoğlu, 2013; Sezgin, 2012; Y1lmazer, 2017). 
$\mathrm{Bu}$ araştırmada psikolojik dayanıklılık ile medenî durum değişkenleri arasında anlamlı bir farklılık bulunmamıştır. Bu bulguya benzer olarak, medeni durum ile psikolojik dayanıklılık arasında anlamlı bir ilişki olmadığını tespit eden çalışmalar mevcuttur (Gökmen, 2014; Kaya, 2018; Ülker-Tümlü ve Recepoğlu, 2013; Sezgin, 2012; Yılmazer, 2017). Buna karşın bu çalışmadan farklı olarak psikolojik dayanıklılık ile medeni durum değişkenleri arasındaki ilişkiyi inceleyen bazı araştırmalarda, evli öğretmenlerin psikolojik dayanıklılık düzeylerinin bekâr öğretmenlerin psikolojik dayanıklılık düzeylerinden daha yüksek olduğu saptanmıştır (Selçuklu, 2013; Uçar, 2014; Nurhat, 2017). Ayrıca bu araştırmada branş değişkenine göre psikolojik dayanıklılık düzeyi farklılaşmamaktadır. Bu bulguya benzer olarak Sezgin (2012) tarafından yapılan bir araştırmada psikolojik dayanıklılı̆̆ın branşa göre farklılaşmadığı saptanmıştır.

Bu çalışmada, görev yapılan okul ile psikolojik dayanıklılık arasında anlamlı bir ilişki olmadığı saptanmıştır. Bu bulguya benzer olarak psikolojik dayanıklılığın görev yapılan okula göre farklılaşmadığını saptayan araştırmalar mevcuttur (Karakaya, 2019; Uçar, 2014; Gökmen, 2014). Bu araştırma bulgularının aksine Sönmezer (2015), psikolojik dayanıklılık ve görev yapılan okul düzeyi arasında anlamlı bir ilişki olduğunu, ilkokulda görev yapan öğretmenlerin psikolojik dayanıklılık düzeylerinin lisede görev yapan öğretmenlerden daha yüksek olduğu sonucuna ulaşmıştır.

Psikolojik dayanıklılık ile yaş değişkeni arasındaki ilişki incelendiğinde araştırma sonuçlarına göre 20-30 yaş arası bireylerde psikolojik dayanıklılık, diğer yaş gruplarına göre yüksektir. Bu düzey yaş ilerledikçe düşmekte ve 36-40 yaş arası bireylerde psikolojik dayanıklılığın diğer yaş gruplarına göre düşük olduğu görülmektedir. 36-40 yaş grubundan sonra psikolojik dayanıklılık düzeyi yükselmektedir. Gençlik çağından yeni çıkmış ve iş hayatına atılarak hayatın sorumluluklarını yeni yeni üslenen düşük yaş gruplarında psikolojik dayanıklılığın yüksek olmasının doğal olduğu düşünülebilir. 36-40 yaş dönemleri artık bireylerin kendi sorumluluklarıyla beraber ailelerinin de sorumluluklarını üstlendiği, bunun yanında meslekte iş hayatındaki yıpranmaların psikolojik dayanıklılığı etkilediği dönemler olduğu düşünülmektedir. Bu bulguya benzer olarak Nurhat (2017) da çalışmasında, yaşın ilerlemesiyle beraber psikolojik dayanıklılığın 
arttığını ortaya koymuştur. Uçar (2014) ve Yalçın (2013) da yaş ile psikolojik dayanıklılık değişkenleri arasında anlamlı bir ilişki olduğunu tespit etmiştir. Buna karşın yaş ile psikolojik dayanıklılık arasında anlamlı herhangi bir ilişki olmadığını saptayan çalışmalar da literatürde yer almaktadır (Karataş, 2016).

$\mathrm{Bu}$ araştırmada öğretmenlerin psikolojik dayanıklılık düzeyleri ile mesleki kıdemleri arasında anlamlı bir ilişki olduğu tespit edilmiştir. Mesleki kıdemi 1-5 yıl ile 21 yıl ve üzeri olan öğretmenlerin psikolojik dayanıklılıkları 11-20 yıl kıdemi olan öğretmenlere göre yüksektir. Mesleki kıdem ile psikolojik dayanıklılık arasındaki ilişki, yaş değişkeni ile psikolojik dayanıklılık arasındaki ilişki ile benzerlik göstermektedir. Yaş ilerledikçe doğal olarak meslekte kıdem de ilerlemektedir. Buna bağlı olarak bir bireyin yaşantıları sonucu elde ettiği deneyim de artmaktadır. Meslek hayatına yeni başlayan öğretmenlerin bir süre sonra heyecanlarını kaybetmeleri, bıkkınlık hisleri, tükenmişlik düzeylerinin artması, stres, ailevi nedenler, örgütsel faktörler gibi etkenler bu ara dönemlerde psikolojik dayanıklılığ 1 olumsuz etkilediği söylenebilir. 21 yıl ve üzeri kıdeme sahibi öğretmenlerde yaş değişkeninde olduğu gibi psikolojik dayanıklılığın arttığı görülmektedir. Bu sonuç; bireyin yaşamında taşların yerine oturması, kabullenme, daha olgun düşünme, deneyimlerin hayata yansıması, yaşın ilerlemesine bağlı olarak tekrar hayata bağlılığın artması gibi nedenlerle açıklanabilir. Yalçın (2013) ve Sönmezer (2015) çalışmalarında benzer sonuçlara ulaşmışlardır.

$\mathrm{Bu}$ araştırmada okuldaki hizmet süresi ile psikolojik dayanıklılık arasında anlamlı bir ilişki olduğu saptanmıştır. Okuldaki hizmet süresi 1-5 yıl arası olan öğretmenlerin psikolojik dayanıklılık düzeyleri 6 yıl ve üzeri hizmet süresi olan öğretmenlere göre yüksektir. Aynı iş yerinde uzun süre çalışıldığında; çatışmalar ve yaşanılan olumsuz deneyimler iş arkadaşları ile olan ilişkilerinin zamanla yıpranmasına neden olabilir. Bu da zamanla psikolojik dayanıklılığın azalmasına neden olabilmektedir. Yalçın (2013), araştırmasında okuldaki hizmet süresi 11-15 yıl olan öğretmenlerin daha az hizmet süresine sahip öğretmenlere göre daha az psikolojik dayanıklılık düzeyine sahip olduklarını ortaya koymuştur. Karataş (2016), hizmet süresinin azalmasiyla beraber psikolojik dayanıklılığın arttığını ortaya koymuşken; Nurhat (2017) psikolojik dayanıklılık ve hizmet süresi arasında bir ilişki olmadığını saptamıştır. 
Tükenmişlik ile demografik değişkenler arasındaki ilişkiler incelendiğinde tükenmişlik ile medeni durum arasında anlamlı bir farklılık bulunmazken; tükenmişlik ile cinsiyet, yaş, kıdem, branş, okuldaki hizmet süresi ve görev yaptığı okul türü değişkenleri arasında anlamlı farklılıklar bulunmaktadır. Bununla birlikte tükenmişlik, medeni duruma göre farklılaşmamaktadır. Bu bulguya benzer sonuçlar elde edilen çalışmalar literatürde mevcuttur (Girgin, 1995; Baysal, 1995; Tümkaya, 1996; Altıntaş, 1997; Yerlikaya, 2000; Izgar, 2001; Başören, 2005; Karataş, 2009; Yılmazer, 2017; Çapri ve Güler, 2018). Bu araştırmanın sonucundan farklı olarak öğretmenlerin medeni durumlarına göre tükenmişlik düzeylerinin farklılaştı̆̆ 1 tespit edilen araştırmalar da mevcuttur (Tümkaya, 1996; Özer, 1998; Cemaloğlu ve Şahin, 2007; Girgin, 2010). Bazı araştırmalar da bekârların evli bireylere göre daha yüksek tükenmişlik yaşadıklarını ortaya koymaktadır (Babaoğlan, 2006; Başol ve Altay, 2009; Yorulmaz ve Altınkurt, 2018). Evli olan bireylerin daha az tükenmişlik yaşamalarının nedenleri olarak; ailevi yaşantıların bireylerin daha çok hayata bağlanmalarını sağlaması, daha sorumlu ve dengeli kararlar alınarak tükenmişlik ile başa çıkmalarını kolaylaştırması gösterilmektedir (Ardıç ve Polatçı, 2008). Bazı araştırmalar ise aksine evlilerin bekârlara göre daha yüksek düzeyde tükenmişlik yaşadıklarını ortaya koymaktadır (Biçen, 2014; Keleş, 2018). Evli bireylerin ailevi sorumluluklarının bekârlara göre daha fazla olması bu durumun nedenlerinden biri olarak açiklanmaktadır (Çoğaltay, Anar ve Karatay, 2017).

Cinsiyet değişkeniyle ilgili elde edilen bulgulara göre kadınlarda zihinsel tükenme düzeyi erkeklere göre daha fazladır. Bu bulguya benzer sonuçlar elde edilen araştırmalar mevcuttur (Dursun, 2000; Forlin, 2001; Yıldız, 2012; Coşkun, 2012). Buna karşın bazı araştırmalarda erkeklerin tükenmişlik düzeylerinin kadınların tükenmişlik düzeylerine oranla daha yüksek olduğu tespit edilmiştir (Torun, 1995; Başol ve Altay, 2009; Seferoğlu, Yıldız ve Avcı Yücel, 2014; Yılmazer, 2017). Bazı araştırmalarda ise cinsiyet değişkeni ile tükenmişlik arasında anlamlı herhangi bir ilişkinin bulunmadığı sonucuna ulaşılmış; cinsiyetin, tükenmişlik üzerinde önemli bir yordayıcı olmadığı ortaya konulmuştur (Çokluk, 1999; Altıntaş, 1997; Yerlikaya, 2000; Seğmenli, 2001; Başören, 2005; Özipek, 2006; Cemaloğlu ve Şahin, 2007; Özcan, 2008; Sezgin, 2009; 
Yalçın, 2013; Çolakoğlu, 2014; Biçen, 2014; Cinay, 2015; Kelgökmen, Saçlı Uzunöz ve Demirhan, 2016; Çapri ve Güler, 2018; Demir Polat, 2018; Keleş, 2018; Korkutan, 2018).

$\mathrm{Bu}$ araştırmanın bulgularına göre 46 yaş ve üzeri bireylerin duygusal tükenme düzeyleri, 20-40 yaş arası bireylerin düzeylerinden düşüktür. Bunun yanında 31-35 yaş aralığındaki bireylerin zihinsel tükenme durumu 41 yaş üzerindeki bireylerden yüksektir. Ayrıca 36-40 yaş arasındaki bireylerin zihinsel ve fiziksel tükenme düzeyi 46 yaş ve üzerindeki bireylerden yüksektir. Nurhat'ın (2017) araştırmasında, öğretmenlerde yaşın artmasıyla beraber tükenmişlik düzeyinin azaldığ 1 saptanmıştır. Yalçın (2013), genç öğretmenlerde tükenmişliğin daha yüksek olduğunu ortaya koymuştur. Aydemir (2013) ise çalışmasında yaş ile tükenmişlik düzeyi arasında herhangi bir ilişki olmadığını saptamıştır.

$\mathrm{Bu}$ araştırmanın bulgularına göre mesleki kıdem değişkenine göre tükenmişlik düzeyleri anlamlı biçimde farklılaştırmaktadır. Kıdemi 6-10 yıl arasında olan öğretmenlerin duygusal tükenme durumu 11-20 yıl kıdemli öğretmenlere göre daha yüksektir. Ayrıca kıdemi 21 yıl ve üzeri olan öğretmenlerin duygusal ve zihinsel tükenme durumu, kıdemi 20 yıldan az olan öğretmenlerden düşüktür. Bunun yanında mesleki kıdemi 11-20 yıl olan öğretmenlerin fiziksel tükenme durumu, 1-5 yıl ve 21 yıl üzeri kıdemli öğretmenlere göre yüksektir. Buna göre kıdem arttıkça duygusal ve zihinsel tükenme düzeylerinin azalmakta olduğu söylenebilir. Bu sonucu, meslekte yeni olan öğretmenlerin tecrübesizlik nedeniyle kendilerini yorgun hissetmeleri, kendilerini bitkin hissetmeleri ve meslekte çalışma şevkinin azalması olarak açıklanabilir. Maslach ve Jackson (1981) da tükenmişlik ile iş tecrübesi arasında negatif bir ilişki olduğunu, öğretmenlerin iş tecrübesi kazanmasıyla başarı algılarının arttı̆̆ını, yorgunluk algılarının azaldığını belirtmektedir (akt. Aslan, 2009). Bu araştırmanın bulguları ile literatürde yapmış bazı araştırmaların bulguları örtüşmektedir (Çimen, 2007; Karakuş, 2008; Aslan, 2009; Yalçın, 2013; Sönmezer, 2015). Buna karşın literatürde kıdemle birlikte doğru orantılı olarak tükenmişliğin de arttığı tespit edilen çalışmalar da mevcuttur (Özcan, 2008; Karataş, 2009).

$\mathrm{Bu}$ araştırmanın bulgularına göre branş öğretmenlerinin zihinsel tükenme düzeyi sınıf öğretmenlerine göre yüksektir. Literatürde, 
öğretmenlerin farklı branşlarda tükenmişliğin sınıf öğretmenlerine göre daha yüksek olduğunu ortaya koyan çalışmalar bulunmaktadır (Tümkaya, 1996; Yalçın, 2013). Gündüz (2004) ve Başaran (1999) çalışmalarında branşın, tükenmişliğin alt boyutlarından özellikle duyarsızlaşma alt boyutunu etkilediğini tespit etmiştir. Bazı araştırmalarda ise özel eğitim öğretmenlerinin tükenmişlik düzeylerinin diğer öğretmenlere göre daha yüksek olduğu saptanmıştır (Çokluk, 1999; Özmen, 2001).

$\mathrm{Bu}$ araştırmada okuldaki hizmet süresinin tükenmişlik düzeyi ile ilişkili olduğu tespit edilmiştir. Buna göre okuldaki hizmet süresi 6-10 yıl arasinda olan bireylerin duygusal ve zihinsel tükenme durumu 1-5 y1 hizmet süresi olan öğretmenlere göre yüksektir. Hizmet süresi 1-5 y1 arasında olan öğretmenlerin ise fiziksel tükenmelerinin 6 yıl ve üzeri hizmet süresi olan öğretmenlere göre düşüktür. Buna karşın Yalçın (2013), okuldaki hizmet süresinin artmasıyla tükenmişlik düzeyinin azaldığını tespit etmiştir.

$\mathrm{Bu}$ araştırmada, ortaokulda görev yapan öğretmenlerin duygusal tükenme düzeylerinin, ilkokulda görev yapanlara göre daha yüksek olduğu tespit edilmiştir. Tümkaya (1997), Özipek (2006), Gündüz (2006) çalışmalarında benzer sonuçlara ulaşmıştır. Bununla birlikte Mo (1991), ortaokul öğretmenlerinin diğer öğretmenlere göre tükenmişlik riskinin daha yüksek olduğunu ortaya koymuştur. Buna karşın Sönmezer (2015) ve Özcan (2008), çalışmalarında okul türü ile mesleki tükenmişlik arasında anlamlı bir ilişkinin olmadığını belirlemiştir.

Psikolojik dayanıklılık ile tükenmişlik arasındaki ilişki incelendiğinde bu araştırmada psikolojik dayanıklılık ile tükenmişlik alt boyutları olan duygusal tükenme, zihinsel tükenme ve fiziksel tükenme arasında negatif yönlü anlamlı ilişki bulunmuştur. Buna göre öğretmenlerde psikolojik dayanıklılık arttıkça tükenmişlik düzeyi azalmaktadır. Literatürde bu bulguya benzer sonuçlar elde eden araştırmalar bulunmaktadır (Azeem, 2010; Bitmiş, Sökmen ve Turgut, 2013; Demir Polat, 2018; Erkutlu, 2012; Ersezgin, 2018; Lopez, Bolano, Marino ve Pol, 2010; Nurhat, 2017; Yalçın, 2013).

$\mathrm{Bu}$ araştırmada elde edilen bulgular genel olarak değerlendirildiğinde, öğretmenlerin kendilerini geliştirmeleri için imkânlar sağlanarak psikolojik dayanıklılıklarının güçlendirilmesi 
sağlanabilir. Bu amaçla öğretmenlerin yetkinliklerinin arttırılması için yüksek lisans ve doktora eğitimleri desteklenebilir, öğretmenlikte kariyer basamakları yeniden düzenlenebilir. Ayrıca öğretmenlik mesleğinin saygınlı̆̆ını arttırıcı çalışmalar yapılabilir ve öğretmenlikte ödül sistemleri yeniden düzenlenebilir. Son olarak öğretmenlerde tükenmişliğe neden olan örgütsel faktörler araştırılabilir ve bu faktörlere yönelik etkili önlemler alınarak alanda uygulamaya konulabilir. 
EXTENDED ABSTRACT

\title{
The Relationship between Teachers' Psychological Resilience and Burnout Levels
}

\author{
Durmuş Bozkurt - A. Faruk Levent \\ Ministry of National Education-Marmara University
}

In this study, in which the relationship between teachers' psychological resilience and burnout levels was examined, it was found that teachers' burnout levels were; with emotional exhaustion, mental exhaustion and physical exhaustion sub-dimensions; was found to be average. It was determined that the total psychological resilience score was above the average. When the relationships between resilience and demographic variables are examined, there is no significant difference between resilience and gender, marital status, branch and school type; There are significant differences between the variables of age, professional seniority and length of service at school.

When the relationships between burnout and demographic variables are examined, there is no significant difference between burnout and marital status; There are significant differences between burnout and variables of gender, age, seniority, branch, length of service at school and type of school. When the relationship between psychological resilience and burnout was examined, a negative and significant relationship was found between emotional exhaustion, mental exhaustion and physical exhaustion, which are the sub-dimensions of psychological resilience and burnout. At the level of total burnout, it was determined that teachers' burnout perceptions were moderate. In addition, according to the findings of this study, it was determined that the total psychological resilience score was above the average.

When the relationships between resilience and demographic variables are examined, there is no significant difference between resilience and gender, marital status, branch and school type; There are significant differences between the variables of age, professional seniority and length of service at school. When the relationship between psychological 
resilience and age variable is examined, according to the results of the research, psychological resilience in individuals between the ages of 2030 is higher than in other age groups. This level decreases as the age progresses, and it is seen that the psychological resilience of individuals between the ages of 36-40 is lower than other age groups. After the age group of 36-40, the level of psychological resilience increases.

In this study, it was determined that there is a significant relationship between teachers' psychological resilience levels and their professional seniority. The psychological resilience of teachers with professional seniority of 1-5 years and 21 years and above is higher than teachers with 11-20 years of seniority. The relationship between professional seniority and resilience is similar to the relationship between age variable and resilience.

When the relationships between burnout and demographic variables are examined, there is no significant difference between burnout and marital status; There are significant differences between burnout and variables of gender, age, seniority, branch, length of service at school and type of school. The emotional exhaustion levels of individuals aged 46 and over are lower than those of individuals aged 20-40. In addition, the mental exhaustion of individuals between the ages of 31-35 is higher than those over the age of 41 . In addition, the level of mental and physical exhaustion of individuals aged 36-40 is higher than individuals aged 46 and over.

According to the findings of this study, burnout levels differ significantly according to the variable of professional seniority. Emotional exhaustion of teachers with a seniority of 6-10 years is higher than teachers with a seniority of 11-20 years. In addition, the emotional and mental exhaustion of teachers with a seniority of 21 years and above is lower than those of teachers with a seniority of less than 20 years. In addition, the physical exhaustion of teachers with 11-20 years of professional seniority is higher than teachers with $1-5$ years and 21 years of seniority. Accordingly, it can be said that as the seniority increases, the emotional and mental exhaustion levels decrease.

According to the findings of this study, the mental exhaustion level of branch teachers is higher than that of classroom teachers. In this study, it was determined that the length of service at the school was related to the 
level of burnout. According to this, the emotional and mental exhaustion of individuals with 6-10 years of service at school is higher than teachers with 1-5 years of service. The physical exhaustion of teachers with a service period of 1-5 years is lower than teachers with a service period of 6 years or more.

According to the findings of this study, the emotional exhaustion levels of teachers working in secondary school are higher than those working in primary school. In addition, a negative significant relationship was found between emotional exhaustion, mental exhaustion and physical exhaustion, which are the sub-dimensions of psychological resilience and burnout. Accordingly, as the psychological resilience of teachers increases, the level of burnout decreases.

When the findings obtained in this study are evaluated in general, it is possible to strengthen the psychological resilience of teachers by providing opportunities for them to improve themselves. For this purpose, graduate and doctorate education can be supported in order to increase the competencies of teachers, and career steps in teaching can be rearranged. In addition, studies can be carried out to increase the prestige of the teaching profession and reward systems in teaching can be rearranged. Finally, organizational factors that cause burnout in teachers can be investigated and effective measures can be taken against these factors and put into practice in the field.

\section{Kaynakça/References}

Altıntaş, E. (1997). Teknik öğretmenlerin tükenmişlik düzeyini etkileyen bazı faktörler ve yordayıcı değişkenler. 4. Ulusal Ĕ̆itim Bilimleri Kongre Bildirileri içinde (ss. 219-244), Eskişehir: Anadolu Üniversitesi.

Ardıç, K. ve Polatçı, S. (2008). Tükenmişlik sendromu akademisyenler üzerinde bir uygulama (GOÜ). Gazi Üniversitesi İktisadi ve İdari Bilimler Fakültesi Dergisi, 10(2), 69-96.

Arı, G. S. ve Bal, E. Ç. (2008). Tükenmişlik kavramı: Birey ve örgütler açısından önemi. Yönetim ve Ekonomi, 15(1), 131-148.

Arıcan, T. (2009). Öğretmenlerde mesleki tükenmişlik ve okul yönetiminde bürokrasi (Yüksek Lisans Tezi). Yeditepe Üniversitesi, Sosyal Bilimler Enstitüsü, İstanbul. 
Aslan, N. (2009). Kars ili ilköğretim okullarında görev yapan öğretmenlerde mesleki tükenmişlik düzeyi. (Yüksek Lisans Tezi). Kafkas Üniversitesi, Eğitim Bilimleri Enstitüsü, Kars.

Aydemir, H. (2013). Özel eğitim alanında çalışan öğretmenlerin tükenmişlik düzeyleri ve yaşam doyumlarının incelenmesi (Yüksek Lisans Tezi). Abant İzzet Baysal Üniversitesi, Eğitim Bilimleri Enstitüsü, Bolu.

Aydın Sünbül, Z. (2016). Ergenlerde bilinçli farkındalık ve kendini toparlama gücü arasındaki ilişki: Öz-duyarlılık ve duygu düzenleme güçlüğ̈̈nün düzenleyici rolü (Doktora Tezi). Ortadoğu Teknik Üniversitesi, Sosyal Bilimler Enstitüsü, Ankara.

Azeem, S. (2010). Personality hardiness, job involvement and job burnout among teachers. International Journal of Vocational and Technical Education, 2(3), 36-40.

Bährer-Kohler, S. (2013). Burnout for experts prevention in the context of living and working. New York: Springer.

Balay, R. (2000). Özel ve resmi liselerde yönetici ve öğretmenlerin örgütsel bă̆hllı̆̆l (Ankara ili örneği). (Doktora Tezi). Ankara Üniversitesi, Sosyal Bilimler Enstitüsü, Ankara

Basım, H. N. ve Ç. F. (2011). Yetişkinler İçin Psikolojik Dayanıklılık Ölçeğinin güvenilirlik ve geçerlilik çalışması. Türk Psikiyatri Dergisi, 22(2), 104114.

Başaran, I. (1999). Zihinsel, görme ve işitme özürlü çocuklara eğitim veren özel eğitim kurumlarında çalışan öğretmenlerin kişilik özelliklerinin belirlenmesi ve karşılaştırılması. (Doktora Tezi). Dokuz Eylül Üniversitesi, Sosyal Bilimler Enstitüsü, İzmir.

Başol, G. ve Altay, M. (2009). Eğ̈tim yöneticisi ve ögretmenlerin mesleki tuikenmişlik düzeylerinin incelenmesi. Kuram ve Uygulamada Egĭtim Yönetimi, 15(58), 191-216.

Başören, M. (2005). Çeşitli değişkenlere göre rehber öğretmenlerin tükenmişlik düzeylerinin incelenmesi (Yüksek Lisans Tezi). Zonguldak Karaelmas Üniversitesi, Sosyal Bilimler Enstitüsü, Zonguldak.

Biçen, H. (2014). Yeni atanan öğretmenlerde tükenmişlik sendromu (Yüksek Lisans Tezi). Dicle Üniversitesi, Eğitim Bilimleri Enstitüsü, Diyarbakır.

Bitmiş, M. G., Sökmen, A. ve Turgut, H. (2013). Psikolojik dayanıklılığın tükenmişlik üzerine etkisi: Örgütsel özdeşleşmenin aracılık rolü. Gazi Üniversitesi Iktisadi ve İdari Bilimler Fakültesi Dergisi, 15(2), 27-40. 
Budak, G. ve Sürgevil, O. (2005). Tükenmişlik ve tükenmişliği etkileyen örgütsel faktörlerin analizine ilişkin akademik personel üzerinde bir uygulama. Dokuz Eylül Üniversitesi İ̈BF Dergisi, 32(2), 95-108.

Cemaloğlu, N. ve Şahin, D. (2007). Öğretmenlerin mesleki tukenmişlik düzeylerinin farklı degiss,kenlere göre incelenmesi. Kastamonu Egĭtim Dergisi, 15(2), 463-484.

Cinay, F. (2015). Illkokul öğretmenlerinin mesleki tükenmişlik düzeyleri ile örgütsel vatandaşlık davranışları arasındaki ilişki. (Yüksek Lisans Tezi). Okan Üniversitesi, Sosyal Bilimler Enstitüsü, İstanbul.

Coşkun, M. K. (2012). Din kültürü ve ahlak bilgisi öğretmenlerinin tükenmişlik düzeylerinin çeşitli değişkenlere göre incelenmesi. Elektronik Sosyal Bilimler Dergisi, 41(41), 64-77.

Çapri, B. (2006). Tükenmişlik ölçeğinin Türkçe uyarlaması: Geçerlik ve güvenirlik çalışması. Mersin Üniversitesi Ĕ̆itim Fakültesi Dergisi, 2(1), 62-77.

Çapri, B. ve Güler, M. (2018). Evaluation of burnout levels in teachers regarding socio demographic variables, job satisfaction and general self-efficacy. Eurasian Journal of Educational Research, 74, 123-144.

Çimen, S. (2007). İlköğretim öğretmenlerinin tükenmişlik yaşantıları ve yeterlilik algıları. (Yüksek Lisans Tezi). Kocaeli Üniversitesi, Sosyal Bilimler Enstitüsü, Kocaeli.

Çokluk, Ö. (1999). Zihinsel ve işitme engelliler okullarında görev yapan yönetici ve öğretmenlerde tükenmişliğin kestirilmesi. (Yüksek Lisans Tezi). Ankara Üniversitesi, Sosyal Bilimler Enstitüsü, Ankara.

Çolakoğlu, İ. (2014). Ortaokullarda görev yapan müzik öğretmenlerinin mesleki tükenmişlik düzeylerinin incelenmesi. (Yüksek Lisans Tezi). İstanbul Aydın Üniversitesi, Sosyal Bilimler Enstitüsü, İstanbul.

Demirbaş, N. (2010). Yaşamda anlam ve yılmazlık (Yüksek Lisans Tezi). Alanya Alaaddin Keykubat Üniversitesi, Sosyal Bilimler Enstitüsü, Antalya.

Demir Polat, D. (2018). Öğretmenlerin yılmazlık düzeyleri ile iş doyumu, mesleki tükenmişlik, örgütsel bağlllk düzeyleri ve örgüt iklimi algıları arasındaki ilişkilerin incelenmesi (Yüksek Lisans Tezi). Sakarya Üniversitesi, Eğitim Bilimleri Enstitüsü, Sakarya.

Dorman, J. (2003). Testing a model for teacher burnout. Austrian Journal of Educational \& Developmental Psychology, 3, 35-47. 
Durak, M. (2002). Predictive role of hardiness on psychological symptomatology of university students experienced earthquake. (Yüksek Lisans Tezi). The Middle East Technical University, Ankara.

Dursun, S. (2000). Öğretmenlerde tükenmişlik ile yükleme biçimi, cinsiyet, eğitim düzeyi ve hizmet süresi değişkenleri arasındaki yordayıcı ilişkilerin incelenmesi. (Yüksek Lisans Tezi). Karadeniz Teknik Üniversitesi, Sosyal Bilimler Enstitüsü, Trabzon.

Ergin, C. (1992). Doktor ve hemşirelerde Tükenmişlik ve Maslach Tükenmişlik Ölçeğinin uyarlanması. (Ed. R. Bayraktar, \& İ. Dağ), VII. Ulusal Psikoloji Kongresi Bilimsel Çalışmaları içinde (ss.143-154). Ankara: Türk Psikologlar Derneği Yayınları.

Ergin, C. (1995). Akademisyenlerde tükenmişlik ve çeşitli stres kaynaklarının incelenmesi. Hacettepe Üniversitesi Edebiyat Fakültesi Dergisi, 12(1-2), 3750.

Ergin, C. (1996). Sağlık personelinin iş anlayışları ve tutumları araştırması. Ankara: T.C. Sağlık Bakanlığı.

Erkutlu, H. (2012). Impact of psychological hardiness and self-monitoring on teacher burnout. H. Ü. Ĕ̆itim Fakültesi Dergisi, 43, 186-197.

Ersezgin, R. (2018). Algzlanan iş stresi ile tükenmişlik düzeyi ve ruh sağhl̆̆ profilinin ilişkisi: Psikolojik dayanıkllık, stresle başa çıkma stilleri ve özduyarllı̆̆ın aracı rolü. (Yüksek Lisans Tezi). Kâtip Çelebi Üniversitesi, Sosyal Bilimler Enstitüsü, İzmir.

Forlin, C. (2001). Inclusion: identifying potential stressors for regular class teachers. Educational Research, 43(3), 235-245.

Gökmen, B. (2014). Özel eğitim okulu yöneticilerinin psikolojik dayanıkllık ve iş doyumları arasındaki ilişkinin incelenmesi. (Yüksek Lisans Tezi). İstanbul Aydın Üniversitesi, Eğitim Bilimleri Enstitüsü, İstanbul.

Gündüz, B. (2004). Öğretmenlerde tükenmişliğin akılcı olmayan inançlar ve mesleki değişkenlere göre yordanması. Mersin Üniversitesi Eğitim Fakültesi Dergisi, 1(1), 152-166.

Gürgan, U. (2006). Grupla psikolojik danışmanın üniversite öğrencilerinin yılmazlık düzeylerine etkisi. (Doktora Tezi). Ankara Üniversitesi, Sosyal Bilimler Enstitüsü, Ankara.

Hock, R. R. (1998). Professional burnout among public school teachers. Public Personnel Management, 17(2), 167-189. 
Karairmak, Ö. (2007). Deprem yaşamış bireylerde psikolojik să̆lamlığa etki eden kişisel faktörlerin incelenmesi: Bir model test etme çalışması (Doktora Tezi). Orta Doğu Teknik Üniversitesi, Sosyal Bilimler Enstitüsü, Ankara.

Karakaya, Y. (2019). Öğretmenlerin psikolojik dayanıklılık ile motivasyon düzeyleri arasındaki ilişkinin incelenmesi. (Yüksek Lisans Tezi). Erzincan Binali Yıldırım Üniversitesi, Sosyal Bilimler Enstitüsü, Erzincan.

Karakuş, G. (2008). Özel ilköğretim ve ortaöğretim kurumlarında çalışan öğretmenlerin tükenmişlik düzeylerinin bazı değişkenlere göre incelenmesi (Yüksek Lisans Tezi). Gazi Üniversitesi, Eğitim Bilimleri Enstitüsü, Ankara.

Karasar, N. (2012). Bilimsel araştırma yöntemi. Ankara: Nobel Yayın Dağıtım.

Karataş, R. (2016). Özel eğitim okullarında çalışan öğretmenlerin psikolojik dayanıklılık düzeyleri ve başa çıkma stratejilerinin incelenmesi. (Yüksek Lisans Tezi). Hacettepe Üniversitesi, Sosyal Bilimler Enstitüsü, Ankara.

Karataş, H. (2009). Öğretmenlerin mesleki tükenmişlikleri ve çok boyutlu algılanan sosyal destekleri arasındaki ilişkinin incelenmesi. (Yüksek Lisans Tezi). Maltepe Üniversitesi, Sosyal Bilimler Enstitüsü, İstanbul.

Karataş, R. (2016). Özel eğitim okullarında çalışan öğretmenlerin psikolojik dayanıklılı düzeyleri ve başa çıkma stratejilerinin incelenmesi (Yüksek Lisans Tezi). Hacettepe Üniversitesi, Sosyal Bilimler Enstitüsü, Ankara.

Keleş, M. (2018). Okul yöneticilerinin psikolojik iyi olma düzeyleri ile tükenmişlik düzeylerinin incelenmesi. (Yüksek Lisans Tezi). Gaziantep Üniversitesi, Eğitim Bilimleri Enstitüsü, Gaziantep.

Kelgökmen, A. H., Saçlı Uzunöz, F. ve Demirhan, G. (2016). Beden Eğitimi öğretmenlerinin tükenmişlik düzeylerinin saptanması ve karşılaştırılması. Kastamonu Ĕ̆itim Dergisi, 24(3), 1503-16.

Korkutan, T. Y. (2018). Meslek liselerinde çalışan öğretmenlerin mesleki doyumu ile tükenmişlik düzeyleri arasındaki ilişkinin incelenmesi. (Yüksek Lisans Tezi). İstanbul Aydın Üniversitesi, Sosyal Bilimler Enstitüsü, İstanbul.

Lopez, J. M., Bolano, C. C., Marino, J. M. ve Pol, E. (2010). Exploring stres, burnout and job dissatisfaction in secondary school teachers. International Journal of Psychology and Psychological Therapy, 10(1), 107123.

Maddi, S. R. ve Khoshaba, D. M. (1994). Hardiness and mental health. Journal of Personality Assessment, 63(2), 265-274. 
Maddi, S., Harvey, R., Khoshaba, D., Lu, J., Persico, M. ve Brow, M. (2006). The personality construct of hardiness, III: Relationships with repression, innovativeness, authoritarianism, and performance. Journal of Personality, 74(2), 575-598.

Maslach, C. ve Goldberg, J. (1998). Prevention of burnout: New perspectives. Applied \& Preventive Psychology, 7, 63-74.

Maslach, C. ve Jackson, S. (1981). The measurement of experienced burnout. Journal of Occupational Behavior, 2(99), 113.

Merriam Webster. (2020). Dictionary. https://www.merriamwebster.com/dictionary/resilience adresinden alındı. Erişim Tarihi: 05.08.2020.

Mo, K. W. (1991). Teacher burnout: relations with stress, personality and social support. Education Journal, 19(1), 5-11.

Nurhat, T. (2017). Özel eğitimde çalışan öğretmenlerin psikolojik dayanıklılık ve tükenmişlik düzeylerinin incelenmesi. (Yüksek Lisans Tezi). Beykent Üniversitesi, Sosyal Bilimler Enstitüsü, İstanbul.

Oruç, S. (2007). Ö̈el egĭtim alanında çalışan ögretmenlerin tukenmiş̧lik düzeylerinin bazı değşskenler açısından incelenmesi. (Yüksek Lisans Tezi). C,ukurova Universitesi, Sosyal Bilimler Enstitüsü, Adana.

Özcan, T. (2008). Pendik bölgesinde görev yapan öğretmenlerin tükenmişlik düzeylerinin bazı demografik değişkenler açısından incelenmesi. (Yüksek Lisans Tezi). Yeditepe Üniversitesi, Sosyal Bilimler Enstitüsü, İstanbul.

Özipek, A. (2006). Ortaöğretim okullarında görev yapan öğretmenlerde mesleki tükenmişlik düzeyi ve nedenleri. (Yüksek Lisans Tezi). Trakya Üniversitesi, Sosyal Bilimler Enstitüsü, Edirne.

Özmen, H. (2001). Görme engelliler okullarında görev yapan öğretmenlerin tükenmişlik düzeyleri. (Yüksek Lisans Tezi). Gazi Üniversitesi, Eğitim Bilimleri Enstitüsü, Ankara.

Peker, R. (2002). Anaokulu, ilkögretim ve lise ögretmenlerinde mesleki tuikenmişliğin bazı değ̌s,kenlere göre incelenmesi. Uludă̆ Üniversitesi Egĭtim Fakültesi Dergisi, 15(1), 305-318.

Pines, A. (2002). A psychoanalytic-existential approach to burnout: demonstrated in the cases of a nurse, a teacher, and a manager. Psychotherapy: Theory/Research/Practice/Training, 39(1), 103-113.

Pines, A. M. ve Aronson, E. (1988). Career burnout: Causes and cures. New York: Free Press. 
Polatçı, S., Gültekin, Z., Irk, E. ve Sobacı, F. (2017). Psikolojik dayanıklılık ve kişilik özellikleri tatmin düzeyini etkiler mi? Süleyman Demirel Üniversitesi Sosyal Bilimler Enstitüsü Dergisi, 2017(4), 553-578.

Seferoğlu, S. S., Yıldız, H. ve Avcı Yücel, Ü. (2014). Öğretmenlerde tükenmişlik: Tükenmişliğin göstergeleri ve bu göstergelerin çeşitli değişkenler açısından incelenmesi. Ĕ̆itim ve Bilim, 39(174), 13-26.

Seğmenli, S. (2001). Rehber öğretmenlerin tükenmişlik düzeylerinin incelenmesi (Yüksek Lisans Tezi). Hacettepe Üniversitesi, Sosyal Bilimler Enstitüsü, Ankara.

Selçuklu, A. E. (2013). Örgütsel bağhlı̆̆ın bir yordayıcısı olarak kurum kültürü ve psikolojik dayanıklılık: okul öncesi öğretmenleri üzerine bir çalışma. (Yüksek Lisans Tezi). Erciyes Üniversitesi, Eğitim Bilimleri Enstitüsü. Kayseri.

Sönmezer, B. (2015). Öğretmenlerin tükenmişlik ve psikolojik dayanıklılık düzeylerinin incelenmesi. (Yüksek Lisans Tezi). Erciyes Üniversitesi Eğitim Bilimleri Enstitüsü.

Sezgin, F. (2009). Relationships between teacher organizational commitment, psychological hardiness and some demographic variables in Turkish primary schools. Journal of Educational Administration, 47(5), 630-651.

Sezgin, F. (2012). İlköğretim okulu öğretmenlerinin psikolojik dayanı1klılık düzeylerinin incelenmesi. Kastamonu Ĕ̆itim Dergisi, 20(2), 489-159.

TDK. (2020). Güncel Türkçe Sözlük. Türk Dil Kurumu: http://www.tdk.gov.tr adresinden alındı. Erişim tarihi: 03.08.2020.

Torun, A. (1995). Tükenmişlik, aile yapısı ve sosyal destek ilişkileri üzerine bir inceleme (Doktora Tezi). Marmara Üniversitesi, Sosyal Bilimler Enstitüsü, İstanbul.

Tümkaya, S. (1996). Ögřetmenlerdeki tukenmişlik görulen psikolojik belirtiler ve başa çıkma davranışları. (Doktora Tezi). Çukurova Üniversitesi, Sosyal Bilimler Enstitüsü, Adana.

Tümkaya, S. (1997, Eylül). Çukurova üniversitesi öğretim elemanlarının akademik değişkenlik düzeyleri. 4. Ulusal Eğitim Bilimleri Kongresi, Eskişehir.

Uçar, T. (2014). Özel eğitim okulu öğretmenlerinin psikolojik dayanıklılı düzeylerinin ve mesleki sosyal destek düzeylerinin bazı değişkenler açısından incelenmesi. (Yüksek Lisans Tezi). İstanbul Aydın Üniversitesi, Eğitim Bilimleri Enstitüsü, İstanbul.

Yalçın, S. (2013). İlköğretim okulu öğretmenlerinin mesleki tükenmişlik düzeyleri ile stres, psikolojik dayaniklilik ve akademik iyimserlik arasindaki ilişki. 
(Yüksek lisans tezi). Gazi Üniversitesi, Eğitim Bilimleri Enstitüsü, Ankara.

Yerlikaya, A. (2000). Köy ve şehirde çalşan sinıf öğretmenlerinde tükenmişlik düzeylerinin incelenmesi. (Yüksek Lisans Tezi). Atatürk Üniversitesi, Sosyal Bilimler Enstitüsü, Erzurum.

Yıldız, E. (2012). Mesleki tükenmişlik ve rehber öğretmenler üzerine bir araştırma. Sosyal Bilimler Enstitüsü Dergisi, 2(33), 37-61.

Yılmazer, F. (2017). Kamu Personeli Seçme Sinavina (KPSS) hazırlanan öğretmen adaylarının sınav kaygisina bağlı olarak tükenmişlik düzeyi ve psikolojik dayanıklılkları. (Yüksek Lisans Tezi). Üsküdar Üniversitesi, Sosyal Bilimler Enstitüsü, İstanbul.

Yöndem, Z. D. ve Bahtiyar, M. (2016). Ergenlerde psikolojik dayanıklılık ve stresle baş etme. The Journal of Academic Social Science Studies, 4(45), 5363.

\section{Kaynakça Bilgisi / Citation Information}

Bozkurt, D. ve Levent, A. F. (2021). Öğretmenlerin psikolojik dayanıklılık ile tükenmişlik düzeyleri arasındaki ilişki. OPUS- Uluslararası Toplum Araştırmaları Dergisi, 18(44), 7968-8000. DOI: 10.26466/opus.937692. 